\title{
The Ecology of the Tropical Compound Ascidian Trididemnum solidum. II. Abundance, Growth and Survival
}

\author{
R. P. M. Bak, J. Sybesma and F. C. van Duyl \\ Caribbean Marine Biological Institute (Carmabi), P.O. Box 2090, Curaçao, Netherlands Antilles
}

\begin{abstract}
The distribution of Trididemnum solidum (Van Name) was investigated in 42 transects over the coral reef on the leeward coast of Curaçao. Ascidian colonies were abundantly present at depths from 1.5 to $34 \mathrm{~m}$ along the central part of this coast, but absent towards the tips of the island. This reflects characteristics of the life history of $T$. solidum, such as short pelagic life, and the local current regime. Another factor influencing the distribution is the ambient light level. For 9 mo, July 1978 to April 1979, we measured the monthly in situ growth of a population varying between 38-50 colonies. Each fortnight these colonies were checked for presence/absence. The constancy in population size masks a highly dynamic system. During our study period 85 novel colonies appeared through division, 43 colonies disappeared through fusion with other colonies and 33 colonles ceased to exist (dead) or were lost. Growth rates were extremely rapid, up to $13 \mathrm{~cm} \mathrm{mo}^{-1}$ in linear direction, compared with the most common spatial competitors (Scleractinia). Although $T$ solidum overgrows corals, growth rates are reduced over living coral tissue. Homogenates of the ascidian had variant but adverse effects on different coral species and, apart from simple overgrowth, allelochemicals could be involved in spatial competition. There is little evidence of predation on Trididemnum solidum and artificial lesions were rapidly regenerated. Our observations show that $T$ solidum had a life span largely exceeding our study period and we suspect that clones may survive indefinitely.
\end{abstract}

\section{INTRODUCTION}

The majority of benthic macro-organisms on coral reefs require hard substrata for settlement, growth and survival. The intensity of competition for this resource is supposed to be high, but there are few quantitative data on processes of competition between sessile organisms in this environment. Stony corals (Scleractinia) are the dominating producers of hard substratum in most of the reef habitats studied in the course of our Institute's coral reef project (Bak, 1975, 1977; van den Hoek et al., 1975, 1978). The corals are spatially competing with neighbouring organisms such as calcareous and filamentous algae, colonial foraminiferans and other scleractinians (Lang, 1970; Potts, 1977; Bak and Engel, 1979; Bak and Steward-Van Es, 1980).

An unusually clear example of such competition on our reefs is the interaction with an encrusting compound ascidian, Trididemnum solidum (Van Name). The margins of colonies of this ascidian are ofter found growing as a lip over the neighbouring coral colonies. The coral tissue under this lip appears to be bleached (indicating a reduction in the density of endosymbiotic algae) and dying. Preliminary observations showed the process of overgrowth to be rapid, up to $1.7 \mathrm{~cm} \mathrm{mo}^{-1}$ (Bak et al., 1977a).

Trididemnum solidum was not only a potentially efficient competitor, it also appeared to be very common in our study area in Curaçao as well as in other parts of the Caribbean, e.g. reefs around Carrie Bow Cay, Belize and in the San Blas Islands, Panamá (Bak, pers. obs.). The absence of $T$. solidum on reefs such as the Discovery Bay Reefs, Jamaica and the northeast coast reefs of Curaçao (Bak, pers. obs.) raised the following questions: Is the Trididemnum population a stable component in an equilibrium or a superior competitor in a non-equilibrium situation? How does this ascidian maintain a high abundance on the hard reef substrata where intense spatial competition and spatial mobility of substrata limit survival (Glynn, 1973; Connell, 1976, 1978; Sebens, 1976; Benayahu and Loya, 1977; Bak and Luckhurst, 1980)?

Abundance, growth of colonies and survival of Trididemnum solidum are the subject of this paper. 
Reproductive strategy, larval behaviour and symbiosis of $T$. solidum with unicellular algae are discussed by Van Duyl et al., 1981 and Sybesma et al., 1981.

\section{MATERIALS AND METHODS}

\section{Abundance on the Reefs}

The island of Curaçao is surrounded by living, fringing coral reefs. To record the abundance of Trididemnum solidum along the leeward coast reefs the ascidians were counted (SCUBA diving) - from May to July 1978 - in $42,5 \mathrm{~m}$ wide transects, laid perpendicular on the shore line to a depth of $60 \mathrm{~m}$ (Fig. 1). These data were supplemented with incidental observations on the relatively inaccessible windward coast. We counted both the individual, separate colonies and the number of clusters of colonies. A cluster was defined as an aggregation of colonies on the same bottom feature, e.g. a large coral head. Our preliminary, and subsequent, data showed that these aggregations originate from 1 colony through division of this colony. There is a possibility that such clusters include recruits sexually produced by cluster members (Van Duyl et al., 1981).

For each colony we recorded depth, mean maximum diameter (mean of maximum diameter and maximum diameter perpendicular on first measurement) and general orientation of colony surface (angle with horizontal plane).

\section{Growth of Colonies}

Because colonies that were detached from their substratum invariably died within a few days, all growth measurements were made on colonies living on their natural substrata in situ. The ascidians do not vary much in thickness and growth is defined as the fluctuation in size of the surface of the colony. The colonies are growing as thin sheets over structurally variable substrata, e.g. a dead coral head, and it was not logistically feasible to measure the actual surface areas of the colonies. To check if records of the mean diameter of a colony served as a reliable indication of colony surface, we tested the relation between measurements of colony surface and mean diameter. The surface of 53 colonies was covered with transparent material, the margin delineated and the resulting area measured using squared paper. The same colonies were subjected to mean diameter measurements. The productmoment correlation between surface values and mean diameter appeared to be highly significant ( $r=0.969$, $\mathrm{p}<0.001$ ). Because it was not possible to fold the material around very complicated structures, this sam- ple was not a random sample of the ascidian population. However, also the colonies we used in our growth measurements did, for obvious reasons, not include the most bizarre colony shapes. The mean diameter measurements are a direct parameter of the colony surface area of our sample.

We measured growth of colonies, from June 30, 1978 to April 4, 1979 with approximately 4 -weekly intervals at 2 locations at the southwest coast of Curaçao: Carmabi Reef (Buoy 1) and Vaersen Bay. The position of each colony or colony cluster was marked with an underwater float.

The size of our initial sample was 38 colonies. The actual number of colonies present at each monthly interval varied from 38 to 50 , due to colony division, colony fusion and disappearance. These phenomena were also recorded. To be able to note the presence or absence of larvae in the test of the colonies, all observations were made when larvae are potentially visible in the test, i.e. between $10.30 \mathrm{~h}$ and $12.00 \mathrm{~h}$. To avoid repetitive lengthy descriptions, colonies with such mature larvae will be termed 'reproductive colonies' in this report, while colonies not displaying any larvae in the surface of the test will be termed 'non-reproductive colonies'. The term reproduction is not used in a strict sense because the last category includes sexually active colonies, but is attached to the possibility to release mature ascidian tadpole larvae.

\section{Substrata and Competitive Interaction}

To investigate the relative importance of the different reef substrata and organisms as potentially limiting factor in spatial competition with Trididemnum solidum, we recorded the number of occurrences the several categories (Table 2) occupied space at the margin of clusters observed during the transect counts. The influence on growth rate of the various neighbouring substrata was noticed during the observations on colony growth.

To see if mechanisms other than simple overgrowth could operate in the interaction with coral, we exposed the 3 most common Scleractinian neighbours: Agaricia agaricites (Linnaeus), Montastrea annularis (Ellis \& Solander) and Eusmilia fastigiata (Pallas) to homogenate of $T$. solidum. To obtain the homogenate $20 \mathrm{ml}$ of a Trididemnum colony was homogenized (within $3 \mathrm{~h}$ after collection) in $80 \mathrm{ml}$ seawater. The homogenate was subsequently filtered (mesh opening $0.1 \mathrm{~mm}$ ) for particles such as large spicules. Quantities of the homogenate were added, directed away from the experimental coral, to $1.5 \mathrm{I}$ glass aquaria to produce the concentrations: 0.001 to 0.004 , and 0.01 . Volumes of seawater were added to the controls $(n=10$ for each 
coral species). The experimental colonies of $A$. agaricites $(\mathrm{n}=40), M$. annularis $(\mathrm{n}=30)$ and E. fastigiata ( $n=71$ ) were kept in the aerated aquaria one day before starting the experiment. Observations continued for $1 \mathrm{wk}$ after adding the homogenate. We recorded 3 possible reaction categories of the corals: (1) No reaction: colonies showed normal patterns of behaviour; (2) reaction: deviation of normal patterns such as initial expansion of tentacles with subsequent retraction, inflation of coral tissue; (3) death: skeleton protrudes through remnants of tissue, no reaction to any stimuli.

\section{Regeneration and Survival}

Every fortnight the colonies used for the growth measurements were checked for survival, predation and degeneration. Survival was monitored in terms of presence or absence of a colony. Predation was noted when we found any traces of bites or grazes on a colony. In addition, during July 1978 we examined the stomach contents of Lactophrys triquetor (Linnaeus). Of the tunicate feeding fishes mentioned by Randall and Hartman (1968) this is the most common species on our reefs.

Degeneration occurs spontaneously in colonies: parts of the colony become covered with a mucus layer and subsequently desintegrate. Some desintegrating colonies were collected in the vicinity of the experimental series, narcotised with menthol, fixed in $40 \%$ and conserved in $4 \%$ formaldehyde. The condition of the tissues was studied using a dissecting microscope.

To investigate the possible impacts of predation and physical damage on Trididemnum solidum we made 2 types of artificial lesions on the colonies. One type $(\mathrm{n}=31)$ consisted of a $50 \mathrm{~mm}^{2}$ circular hole, punched out the test of a colony, the other $(n=26)$ of grazes. Grazes were made moving a $1 \times 2 \mathrm{~cm}$ sandpapered cube a $4 \mathrm{~cm}$ distance over the colony surface. The resulting $10 \mathrm{~cm}^{2}$ superficial wound grazed approximately a $2.5 \mathrm{~mm}$ layer off the colony. The first series of lesions was inflicted on March 1, 1979, at depths from 3 to $22 \mathrm{~m}_{\mathrm{i}}$ the second series on March 12, 1979, at depths from 6 to $26 \mathrm{~m}$. We measured the diameter of the lesions and observed the regeneration process at 2 to 4 d intervals.

\section{RESULTS}

\section{Abundance on the Reefs}

The distribution and abundance of Trididemnum solidum along the coast is shown in Fig. 1. The abund-
Fig. 1. Map of Curaçao with 42 transects (Arrows 1 to 42) and additional observations (arrows marked with asterisk). Lower graph: number of colonies in transects. Transects are scaled to distance along the abscissa (representing the $69 \mathrm{~km}$ long southwest coast)

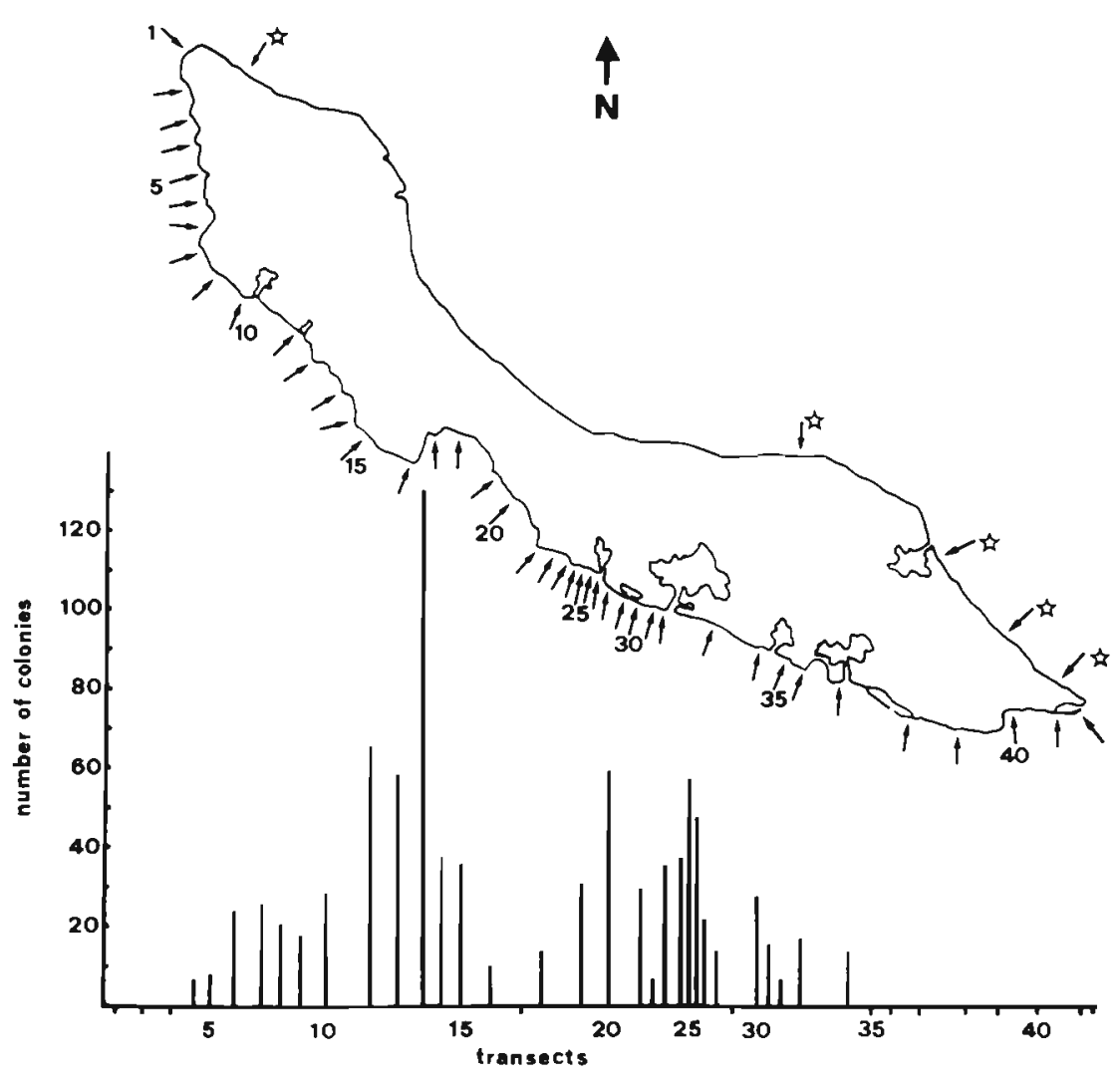




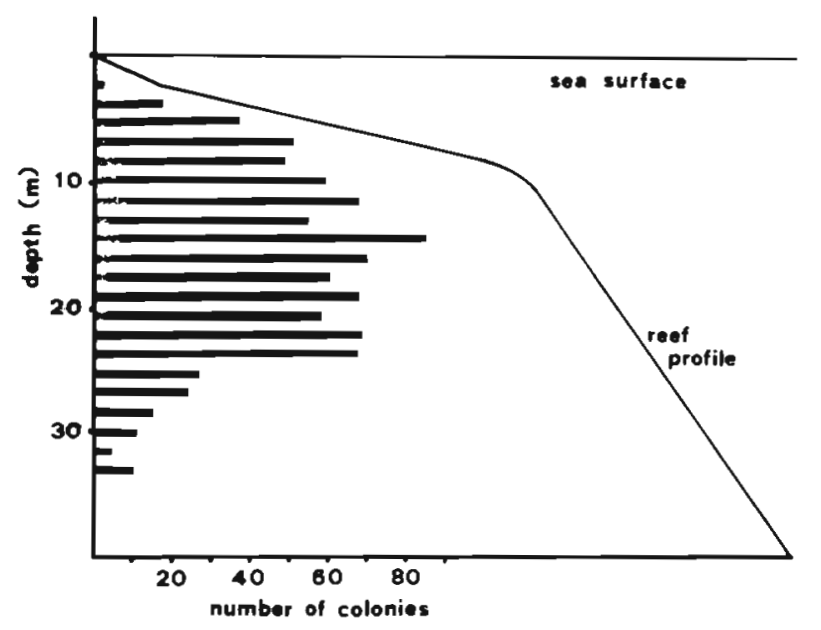

Fig. 2. Trididemnum solidum. Abundance of colonies with depth over a generalized profile of the reef. Dotted basal parts of bars indicate number of colonies with colony surface area deviating $\geqslant 45^{\circ}$ from horizontal plane

ance of clusters and colonies showed the same pattern. During the survey we found no $T$. solidum towards the tips of the island. In the populated area along the coast were gaps in the continuous distribution at Stations 17 and 29. Observations made apart from this survey confirm these results. No $T$. solidum colonies were found on the northeast coast or on the southwest coast outside the area confined by Transects 4 and 34 . The exception is one recent find of a cluster of 3 small colonies at Station 41 (Feb. 27, 1980).

The abundance of the ascidian colonies along the depth gradient is shown in Fig. 2. Again the pattern is the same for clusters and for colonies. Although both reef profile and abundance of Trididemnum solidum vary along the coast, which accounts for the broad range of maximum abundance, it appears that the ascidian occurs neither in the very shallow $(<1.5 \mathrm{~m})$ nor in the deep reef $(>34 \mathrm{~m}$ ). The number of colonies growing relatively cryptically, with colony surfaces at angles $45^{\circ}$ to $90^{\circ}$ with the horizontal plane (sea surface), is small but entirely confined to the upper part of the depth range (Fig. 2). The size of the colonies in the population appeared not to vary with depth (productmoment correlation $\mathrm{p}>0.1$ ).

\section{Growth of Colonies}

As in other compound ascidians, growth in Trididemnum solidum proved to be a highly complex phenomenon. Colonies increased and decreased, divided, fused and disappeared throughout the year An example of these complicated patterns is shown in Fig. 3. The mean dlameter, and thus surface area, of the colonies and the number of colonies changes throughout the year (Table 1). A small mean diameter is correlated (product-moment correlation $r=0.839$, $\mathrm{p}<0.01$ ) with a high number of colonies and vice versa. This reflects the influence of division and fusion. When seawater temperatures are higher than $27^{\circ} \mathrm{C}$, colonies are significantly larger and less numerous than at lower temperatures ( $\mathrm{t}$-test, $\mathrm{t}=3.524 \mathrm{t} \mathrm{t}=3.494$, $\mathrm{p}<0.01$ ).

Division was mostly initiated by decay of part of a colony. After a mucus layer covers part of the colony this part disintegrates. The zooids are absent in the decaying test. In the normal looking part of such a colony the zooids show no degeneration, while in transitional areas the upper test part with the thoraces had disappeared. This phenomenon involves a decrease in surface area and sometimes disappearance

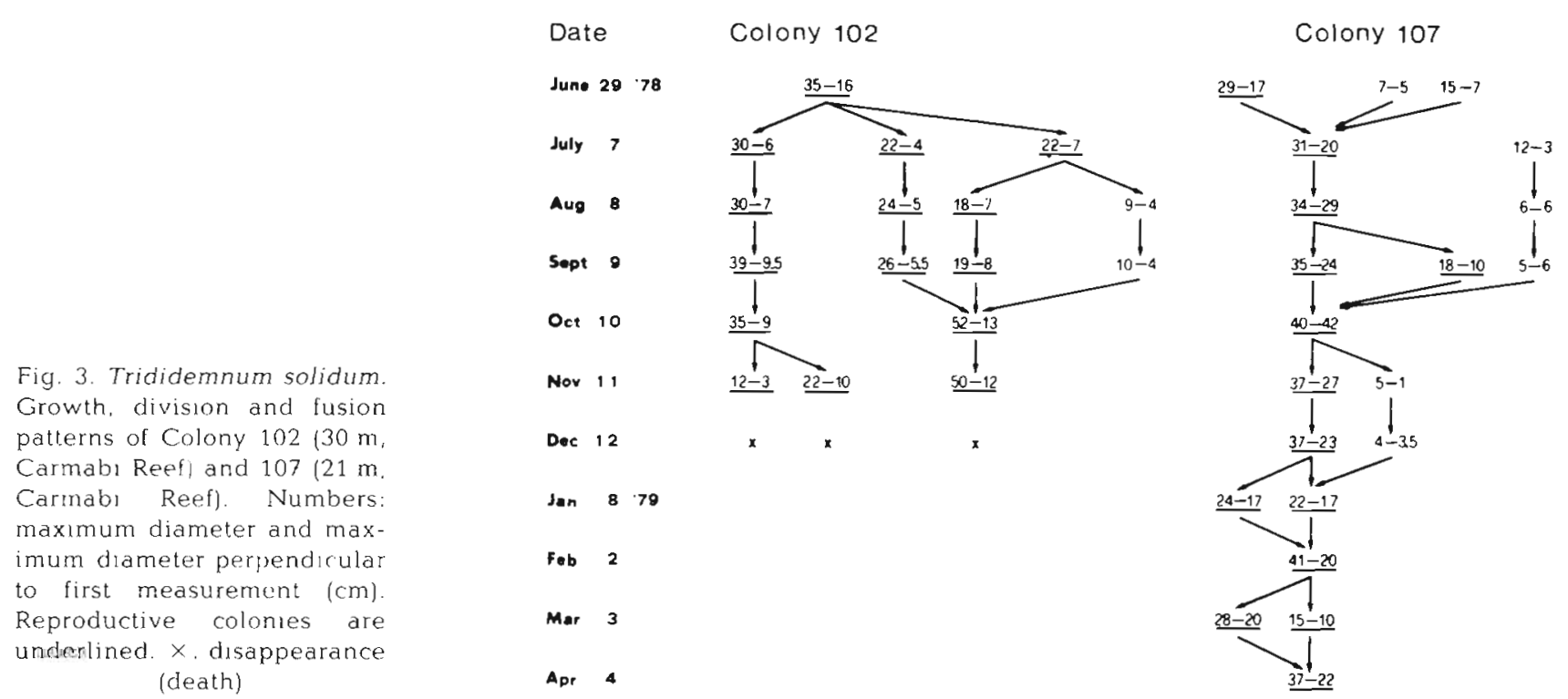


Table 1 Trididemnum solidum. Number and size of colonies during observation period. Mean temperature measured at $10 \mathrm{~m}$ depth

\begin{tabular}{|c|c|c|c|c|c|}
\hline Time period & $N$ & $\begin{array}{c}\text { All colonies } \\
\text { (mean diameter, } \\
\mathrm{cm} \text { ) }\end{array}$ & $\begin{array}{c}\text { Reproductive } \\
\text { colonies } \\
\text { (mean diameter, } \\
\mathrm{cm} \text { ) }\end{array}$ & $\begin{array}{c}\text { Non-reproductive } \\
\text { colonies } \\
\text { (mean diameter, } \\
\mathrm{cm} \text { ) }\end{array}$ & $\begin{array}{c}\text { Mean } \\
\text { temperature } \\
\left({ }^{\circ} \mathrm{C}\right)\end{array}$ \\
\hline $30 / 6-4 / 71978$ & 38 & 18 & 32.9 & 12.2 & 27.5 \\
\hline $24-25 / 7$ & 41 & 18.8 & 28.1 & 10.4 & 27.3 \\
\hline $17-18.8$ & 39 & 20.6 & 28.4 & 11.7 & 27.5 \\
\hline $18-19 / 9$ & 40 & 21.8 & 28.2 & 9.9 & 27.2 \\
\hline $16-17 \cdot 10$ & 43 & 18.6 & 24.4 & 8.4 & 28 \\
\hline $13-14 / 11$ & 43 & 18.9 & 25.8 & 7.1 & 27.9 \\
\hline $\begin{array}{ll}11 & -12.12\end{array}$ & 48 & 15.1 & 18.8 & 7.4 & 27.4 \\
\hline $8-9 / 11979$ & 50 & 15.8 & 21.8 & 8.8 & 26.5 \\
\hline $5-6.2$ & 46 & 14.3 & 21.3 & 8.0 & 26.6 \\
\hline $5-6 / 3$ & 50 & 14 & 25.4 & 9.2 & 26.4 \\
\hline $3-4 / 4$ & 47 & 15.4 & 30.8 & 11 & 26.4 \\
\hline
\end{tabular}

of the colony. A much rarer form of division in $T$. solidum is colonial budding (Oka and Usui, 1944), i.e. division of a small part of a colony without any disintegration and without change in surface area. Fusion between colonies occurs often. Colonies grow towards each other, the margins meet and fusion may occur after a few weeks or months, during which period a fissure remains between the colonies.

Although disintegration is involved in the division of colonies, it most often occurs without such an effect. Small parts of colonies are frequently disintegrating. This occurs especially in the large, reproductive colonies, which appear to be significantly more prone to disintegration of small parts than non-reproductive colonies ( $\chi^{2}$ test, $\left.\mathrm{p}<0.001\right)$. There are 2 relations here. Firstly, between the number of disintegrations and water temperature. Disintegration is significantly more common above $27^{\circ} \mathrm{C}\left(\chi^{2}\right.$ test, $\left.\mathrm{p}<0.01\right)$. This is the part of the year that larger colonies dominate the population (Table 1). Secondly, reproductive colonies had a significantly larger mean size than non-reproductive colonies ( $\mathrm{t}$-test, $\mathrm{t}=11.969, \mathrm{p}<0.001$ ). In conclusion, decay of small test areas is most common during the warmer part of the year in large reproductive colonies.

Of course, the minimum size of reproductive colonies is much smaller. Here we must differentiate between colonies which are not reproducing until a certain size is reached and colonies originating through division from reproductive colonies. In the first category, larvae are produced at a minimum colony size of $9 \mathrm{~cm}$ (mean diameter). In the second group, colonies produce larvae at the very small size of $2.5 \mathrm{~cm}$ (mean diameter).

We could not find significant relations of increase or decrease in size with water temperatures or with sun hours (recorded with a Campbell-Stokes sunshine recorder at Curaçao Airport). We found no correlation between increase or decrease in colony diameter with depth. A comparison of the potential mean increase of colony diameter (mean of positive measurements) at $0-14,14-18$, and $>18 \mathrm{~m}$ showed no variation with an increase of $2.8,2.8$, and $2.6 \mathrm{~cm} 4 \mathrm{wk}^{-1}$, respectively.

There is, however, a significant difference in growth between reproductive colonies compared with nonreproductive colonies. Colonies which produced larvae grew significantly more slowly over the 9 mo time interval than colonies without larvae ( $t$-test, $t=0.961$, $\mathrm{p}<0.001$ ). While the net gain in size is lower in larvae producing colonies, it appeared nevertheless that these are the colonies most capable of rapid increase in size (Fig. 4). These are swift fluctuations on a much smaller time scale than the 9 mo interval.

Fig. 4 shows all growth increments measured. The ascidians could cover the substratum with a maximum

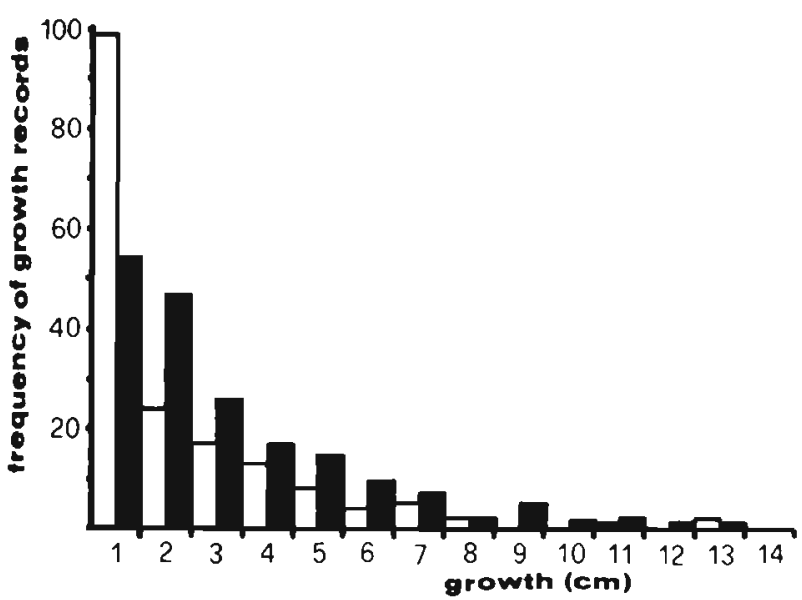

Fig. 4. Trididemnum solidum. Growth records (diameter increments each 4 wk period) collected from June 30, 1978 to April 3, 1979. White bars: non-reproductive colonies; black bars: reproductive colonies 
rate of $13 \mathrm{~cm} 4 \mathrm{wk}^{-1}$. Such rapid growth was only observed over unoccupied rock, i.e. rock covered with a sparse turf of filamentous algae. Maximum growth rate measured over living coral was $2.8 \mathrm{~cm}$. This differentiation in growth rates over different types of substrata results in colonies expanding rapidly over rocky substratum, avoiding living coral surfaces. Corals appeared to become overgrown when other possibilities for colony expansion were exhausted.

\section{Substrata and Competitive Interaction}

The frequency of occurrence of neighbouring organisms and types of substrata is shown in Table 2 . The most common substratum is rock covered with thin algal turf. Total occurrence of scleractinian corals bordering on Trididemnum solidum is $43.5 \%$. Although these data only give the number of occurrences, i.e.

Table 2. Frequency of occurrence (\%) of neighbouring organisms and substrata at margins of Trididemnum solidum clus ters along 31 transects perpendicular to the coast $(n=865)$

$\begin{array}{lr}\text { Eusmilia fastigiata } & 10.9 \\ \text { Montastrea annularis } & 8.3 \\ \text { Agaricia agaricites } & 7.8 \\ \text { Montastrea cavernosa } & 2.9 \\ \text { Colpophyllia natans } & 2.5 \\ \text { Siderastrea siderea } & 2.2 \\ \text { Meandrina meandrites } & 1.5 \\ \text { Madracis decactis } & 1.4 \\ \text { Stephanocoenia michelinii } & 1.2 \\ \text { Madracis mirabilis } & 1.0 \\ \text { Other scleractinian corals } & 3.8 \\ \text { Millepora sp. and Gypsina sp. } & 1.6 \\ \text { Octocorals } & 1.3 \\ \text { Excavating sponges } & 2.2 \\ \text { Other sponges } & 8.2 \\ \text { Crustose coralline algae } & 4.0 \\ \text { Blue-green algae } & 3.9 \\ \text { Rock with thin algal turf } & 28.7 \\ \text { Rock with dense vegetation } & 6.4 \\ \text { Coral rubble and sand } & .2\end{array}$

encounters, this high frequency indicates the intensity of competition for space between these organisms

The 3 most common single species marginal to the ascidian colonies are Eusmilia fastigiata (10.9\%), Montastrea annularis $(8.3 \%)$, and Agaricia agaricites $(7.8 \%)$. Because ascidians are known to possess poisonous substances (Burkholder, 1973), we assumed that apart from simple overgrowth of the rim of the extending colony, allelopathic chemicals could be involved. Table 3 shows that the 3 experimental coral species were reacting to homogenate of Trididemnum solidum. There appeared to be little variation in the reaction at different concentrations, but the reaction does vary between the coral species. A agaricites displays the highest sensitivity.

\section{Survival, Predation, Regeneration}

The dynamics of the studied populations of Trididemnum solidum are of a magnitude of complexity comparable to the intricate growth processes. When the size of the initial sample, consisting of 38 colonies, is compared with the numbers present at observations during the 9 mo period (Table 1) and the sample size of 47 colonies at the end of our study, the population appears to be rather stable. However, during these $9 \mathrm{mo}, 22$ colonies disappeared and 11 were lost (due to logistical errors), a total of 33 colonies or $87 \%$ of original sample size. This decrement was easily compensated for by the 85 novel colonies (224\% original sample size), appearing through division of colonies. Fusion occurred 43 times, too infrequently to compensate for division. The total result of this highly dynamic system is a remarkable constancy in colony numbers during our study.

We suspect the 38 colonies originally present to represent 34 clones (single colonies or groups of colonies on separate bottom features - e.g. a small coral patch - characterized by division and fusion between group members). After 9 mo, 6 clones or $18 \%$ of those

Table 3. Reactions of 3 coral species to homogenate of $T_{r}$ ididemnum solidum. ( $\mathrm{N}=$ number of colonies)

\begin{tabular}{|c|c|c|c|c|c|}
\hline Coral species & $N$ & Homogenate concentration & No reaction & Reaction & Dead \\
\hline Eusmilia fastigiata & $\begin{array}{r}10 \\
56 \\
5\end{array}$ & $\begin{array}{l}0 \\
0.001 / 0.004 \\
0.01\end{array}$ & $\begin{array}{r}10 \\
29 \\
4\end{array}$ & 27 & 1 \\
\hline Montastrea annularis & $\begin{array}{r}10 \\
15 \\
5\end{array}$ & $\begin{array}{l}0 \\
0.001 / 0.004 \\
0.01\end{array}$ & $\begin{array}{r}10 \\
1\end{array}$ & $\begin{array}{l}9 \\
5\end{array}$ & 5 \\
\hline Agaricia agaricites & $\begin{array}{r}10 \\
25 \\
5\end{array}$ & $\begin{array}{l}0 \\
0.001 / 0.004 \\
0.01\end{array}$ & 10 & 8 & $\begin{array}{r}17 \\
5\end{array}$ \\
\hline
\end{tabular}


originally present had disappeared. We have no evidence of the establishment of new clones in this reef area.

Predation on the ascidians was a rare event. During our observation period only $2.8 \%$ of our checks on signs of predation were positive. These small lesions were always regenerated at the time of our next fortnightly observation. Examination of stomach contents of a feasible predator, Lactophrys triquetor, produced no remains of the tough ascidian tests.

The regeneration experiments showed that, after infliction of a lesion, tissue at the margin of the lesion was shed by the rest of the colony. Although this resulted in initial enlargement of the wound (Fig. 5), the damage never induced the vast decay naturally occurring in the ascidians. The majority of the artificial grazes $(85 \%)$ developed into complete holes through the test. Fig. 5 shows regeneration of both types of lesions in terms of surface area. Regeneration in terms of number of lesions completely closed is shown in

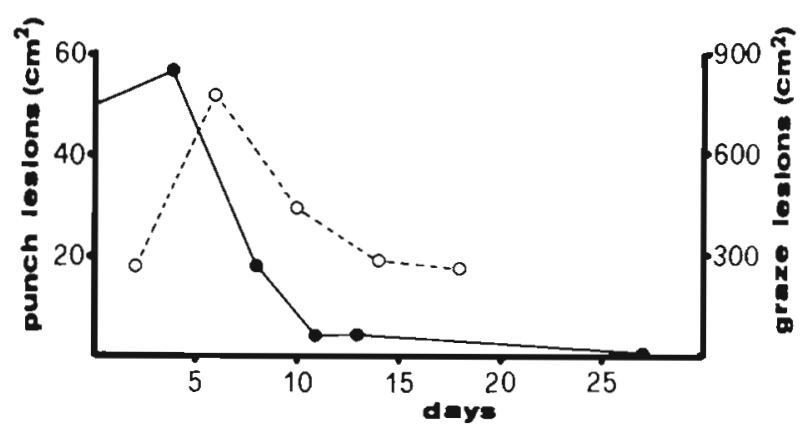

Fig. 5. Trididemnum solidum. Mean size of holes resulting from $50 \mathrm{~mm}^{2}$ punch lesions ( $\mathrm{n}=31$, unbroken line) and $1000 \mathrm{~mm}^{2}$ graze lesions ( $\mathrm{n}=26$, broken line). Observations made for 27 and $18 \mathrm{~d}$ after infliction of the lesions, respectively

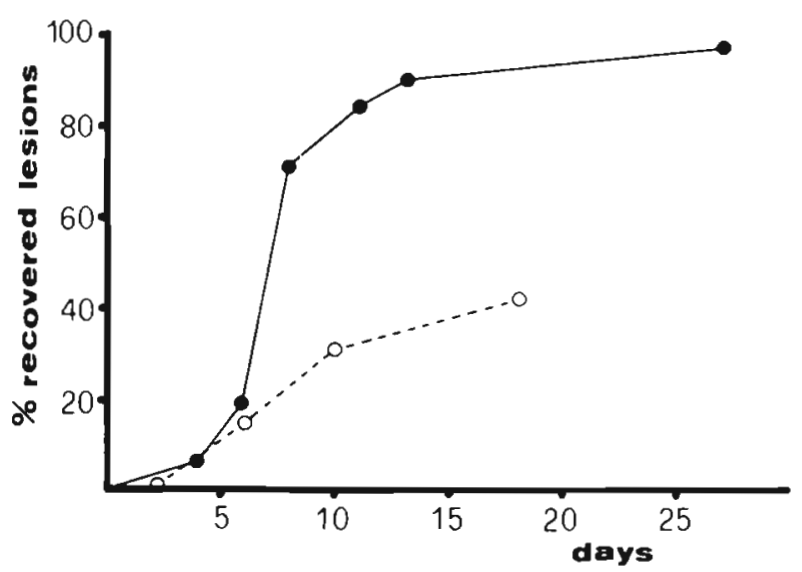

Fig. 6. Trididemnum solidum. Regeneration of punch and graze lesions, expressed as percentage of lesions completely recovered. Closed circles: $50 \mathrm{~mm}^{2}$ punch lesions $(\mathrm{n}=31)$; open circles: $1000 \mathrm{~mm}^{2}$ graze lesions ( $\mathrm{n}=26$ )
Fig. 6. The original size of the lesion has an obvious effect and regeneration of large holes in the test is comparatively slow. We found no difference in regeneration capability in shallow $(3-10 \mathrm{~m})$ and deeper water $(14-20 \mathrm{~m})$.

\section{DISCUSSION}

Trididemnum solidum is evenly distributed along the central part of the southwest coast of the island. Exceptionally high numbers of colonies, i.e. at Transect 13 (Fig. 1), are caused by the exceptional length of the transect. The few gaps in the otherwise continuous population, Transects 17 and 29, and relatively low numbers, Transect 16 , and 18 are probably the result of local pollution. Transect 16, and 18 are downcurrent of the Curaçao Oil Terminal. Small but frequent oil spills are expected to influence the biota on these reefs. Transect 29 is at the discharge of the Island's Water Distillation Plant. At this locality seawater temperature was $3^{\circ} \mathrm{C}$ higher than ambient temperatures during the survey. There are no data concerning possible chronic chemical pollution of this site.

We propose that the absence of Trididemnum solidum on the reefs towards the tips of the island is related to characteristics of the current regime and its influence on the dispersal of pelagic larvae. The eastern current in this part of the Caribbean divides at the eastern tip of the island in a strong and persistent current running along the exposed northeast coast and an equally persistent but weaker current along the leeward southwest coast. Eddy formation is known to occur along the uneven coastline of the central part of the leeward coast.

Considering the short free-swimming life of the Trididemnum solidum larvae (Van Duyl et al., 1981), as well as the usual current velocity ( $<1$ knot), the majority of the larvae have a maximum dispersal range of $\pm 400 \mathrm{~m}$. The few larvae we have followed in situ during their pelagic life span actually settled within $10 \mathrm{~m}$ of the parent colony. The chance of such larvae to colonize the reefs up-current, towards the eastern tip of the island, is very small. Although we have only few data, it is probable that a persistent eddy exists at the western tip of the island and that the resulting counter current in a southeastern direction, along this part of the coast, limits the dispersal of $T$. solidum larvae into that area. That the reef habitat itself is suitable for settlement is shown by a recent observation of a cluster of 3 small colonies at Transect 41 . It is unlikely that such a small number of accidental recruits is sufficient to establish an ascidian population (Kott, 1974). The relatively weak current, local eddy formation and short pelagic life of larvae are factors that promote the per- 
sistency of the ascidian population at the central part of the leeward coast.

The absence of Trididemnum solidum at the exposed northeast coast may be caused by the different set of physical parameters, especially the stronger current, and/or by a difference in reef structure. Probably the local current conditions coupled with the small potential of up-current colonization of suitable reef areas are responsible. $T$. solidum is absent on reefs at the exposed Jamaican north coast, but occurred at an exposed incipient algal ridge in the San Blas Archipel. Panamá (Bak, pers. obs.)

The vertical distribution over the reef is at least partly determined by the submarine light regimes and the availability of hard substrata. Trididemnum solidum is host to unicellular endosymbiotic algae and the response of the algal-ascidian unit to ambient light will limit the distribution in deeper water. Although a small part of the population shows a preference for a more cryptic micro-habitat in the shallower part of the depth range, many colonies grow fully exposed to light at depths as shallow as $1.5 \mathrm{~m}$. One of us (Bak) found $T$. solidum colonies growing just below the sea surface in San Blas (Panamá). However, the shallow part of the reef terrace has much more sandy areas than the deeper part of the terrace and the reef slope, and as such is less suitable for extensive growth of $T$. solidum. Also, a high level of environmental disturbance in the shallower part of the reef may inhibit survival of ascidian colonies

Although Trididemnum solidum larvae are not well adapted for dispersal, they are very well equipped, with their tail and sense organs (Kott, 1974; Van Duyl et al., 1981), for site selection. That colonies grow to large size over the whole range of occurrence indicates that these habitats are not physiologically marginal, and confirms the site selection capacities of the larvae.

A whole series of odd growth phenomena is associated with compound ascidians. Some species display fusion (Oka and Watanabe, 1957; Carlisle, 1961; Mukai and Watanabe, 1974; Morgan, 1977; Osman, 1977), division (Oka and Usui, 1944; Carlisle, 1961; Goodbody, 1965; Lafargue, 1972) colonial budding (Oka and Usui, 1944) or show periodic rejuvenescence (Millar, 1971). Trididemnum solidum shows frequent rejuvenescence as well as all other mentioned phenomena. It is unclear if $T$ solidum is unique in this respect because studies on tropical compound ascidians similar to ours are not reported in the literature.

Although the colonies probably do not actually creep over the substrata as observed in a few species (Carlisle, 1961; Monniot, 1962; Lafargue, 1972), the result of the frequent occurrence of degeneration and proliferation, fusion, division and colonial budding is that colonies are spatially very mobile. Bak and Luckhurst
(1980) showed the changes in spatial arrangement of bottom component (e.g. rock, sand, coral species) at the study reef to be considerable. After 5 yr $51-42 \%$ of substratum components had changed position in quadrats at 10 and $20 \mathrm{~m}$ depth. It appears that the combination of a high potential of spatial rearrangement of colonies, potentially high linear growth rates, and a continuous supply of tadpole larvae makes $T$. solidum an efficient occupier of hard substrata, well adjusted to the magnitude of change (e.g. collapse and renewal) in this habitat.

None of the factors - temperature, depth, number of sun hours per unit time - could be related with growth per se. The colonies are larger and more capable of rapid growth when the temperature is $>27^{\circ} \mathrm{C}$. At such temperature there is also more decay and a higher production of free-swimming larvae. The effect of a rise in temperature over $27^{\circ} \mathrm{C}$ appears to be an increase in the rate of physiological processes.

Many compound ascidians show either alternate periods of maximum asexual (growth) and sexual reproduction (Berrill, 1948; Millar, 1952, 1971; Haven, 1971; Morgan, 1977) or after initial growth have one sexually active phase before death of the colony (Millar, 1952; Yamaguchi, 1975; Morgan, 1977). A separation of the phases of maximal asexual and sexual reproduction is linked with factors such as temperature (Millar, 1971), available substratum (Yamaguchi, 1975) and allocation of energy within a colony (Millar, 1952).

We found no similar separate periods in Trididemnum solidum. In this species colonies go through long periods of larval production, subsequently followed by periods of rest. There is no synchronization of this phenomenon throughout the population. However, the process is complicated by fusion and division. Reproductive colonies may split up in colonies which are not reproductively active. Alternatively, reproductive and non-reproductive colonies may fuse (Fig. 2).

We have no evidence for a phase of experimental growth in Trididemnum solidum such as observed in other compound ascidians (Oka and Usui, 1944; Yamaguchi, 1975; Morgan, 1977). Such experimental growth occurs when the ascidian recruits, after metamorphosis, grow to reproductive age (size) or till the available substratum is occupied. Most if not all of the colonies we observed did not belong to this age class. They were either small but originating from division, or larger and in competition for space with other benthic organisms. The difference in maximum growth rates over dead and living corals (13 and $2.8 \mathrm{~cm} 4 \mathrm{wk}^{-1}$, respectively) demonstrates the limiting effects of spatial competitors. Morgan (1977) observed contact with other organisms to inhibit growth in Botrylloides nigrum Herdman and Aplidum lobatum Savigny. The symbiosis of $T$. solidum with symbiotic algae makes 
food an unlikely limiting resource with respect to exponential growth

Trididemnum solidum appears to be totally restricted to life on hard substrata. Only $0.2 \%$ of the colonies in our transects had colony margins in contact with coral rubble and sand (Table 2), the remainder bordering on rock and epigrowing organisms. Competition with corals must be important because $43.5 \%$ of all encounters is with coral species (Table 2). Eusmilia fastigiata, Montastrea annularis and Agaricia agaricites, the most common neighbours to $T$. solidum, are very common scleractinians at the depth where $T$. solidum reached its highest abundance. In addition, these corals offer crevices between the branches or blades of their colonies which may attract free-swimming larvae and enhance survival of $T$. solidum recruits and small colonies.

Although there is a large difference between the potential growth rates of the living margins of scleractinian corals and Trididemnum solidum, the ascidian usually avoids growing over the living coral surfaces and rather occupies the other substrata before extending the rim of the colony over living coral. Apart from the higher growth rate, $T$. solidum is potentially able to release allelopathic chemicals. It has been suggested that such chemicals are of importance in other groups of marine organisms (Jackson and Buss, 1975; Vadas, 1979). Our experiments with homogenates of T. solidum indicate a differentiation in the reaction of the various coral species. Not much is known of the life history of Eusmilia fastigiata, but the relative magnitude of the reaction of Agaricia agaricites and Montastrea annularis fits in nicely with their life history patterns. A. agaricites and $M$. annularis may be thought of, respectively, as more and less opportunistic species or as having more $r$ strategist versus $\mathrm{K}$ strategist characteristics (Bak and Engel, 1979; Bak and Luckhurst, 1980). It would be of interest to observe possible variation in growth rates of $T$ solidum over more and less opportunistic coral species.

The longevity of compound ascidians varies from a few months to a few years ( 3 mo to $5 \mathrm{yr}$; Millar, 1971; Morgan, 1977). During our 9 mo study period individual colonies as well as the products of fusion and division survived. The stability of size in various colonies suggested that the life-span of Trididemnum solidum is much larger than our period of observation. Of course, individual colonies died (disappeared) during these $9 \mathrm{mo}$, but it is unknown how much of the original recruit remained alive in other colonies through the common processes of division and fusion. In this sense $T$. solidum may be potentially immortal.

The cause of death of the colonies which disappeared between consecutive censusses we assume to be some physiological process, probably related to the frequent partial decay of colonies, lacking in this case simultaneous rejuvenescence. No other cause of death seems likely. The colonies are always firmly attached to the substratum. There is little predation on colony surfaces. Lesions regenerate rapidly. Although environmental disturbance, such as collapse of substratum, commonly occurs in the study area (Bak and Luckhurst, 1980), only few colonies were thus destroyed.

The regeneration of lesions in Trididemnum solidum is remarkably more rapid than in their most important spatial competitors: the scleractinian corals. We studied regeneration in 4 species of coral at the same reef (Bak et al., 1977 b; Bak, 1978; Bak and StewardVan Es, 1980). In the fastest regenerator listed (Acropora palmata Lamarck) the first $\left(1 \mathrm{~cm}^{2}\right)$ artificial lesions were completely recovered after $5 \mathrm{wk}$. In $T$. solidum $30 \%$ of larger and $80 \%$ of smaller lesions are completely recovered after only $2 \mathrm{wk}$ (Fig. 6).

In conclusion, Trididemnum solidum appears to be a very dynamic organism. Possibilities of dispersal are low, but in a sufficiently dense population, maintenance potential is high because of: (1) The relatively high mobility of the colonies over the substratum through division, colonial budding, fusion and rapid growth; (2) effective competition for space through rapidly overgrowing margins (lips) with possible allelochemical effects; (3) low predation pressure and high regeneration capacity; (4) long life-span of colonies or clones and continually available free-swimming larvae.

Acknowledgements. We are grateful to Oscar Frans, Frank Isabella and Aubrey Tiel for their assistance on the reef, and thank Dr. R. H. Millar (Scotland) for reading the manuscript. The second author was supported by a grant from the Beyerinck-Popping Fund, Holland.

\section{LITERATURE CITED}

Bak, R. P. M. (1975). Ecological aspects of the distribution of reef corals in the Netherlands Antilles. Bijdr. Dierk. 45: 181-190

Bak, R. P. M. (1977). Coral reefs and their zonation in the Netherlands Antilles. Stud. Geol. 4 AAPG Tulsa: 3-16

Bak, R. P. M. (1979). Growth and regeneration in the scleractinian reef coral Acropora palmata. Proc. Assoc. Is. Mar. Labs. Carib. Santo Domingo 14:13

Bak, R. P. M., Brouns, J. J. W. M., Heys, F. M. L. (1977a). Competitive interactions between corals and other benthic reef organisms. Proc. Assoc. Is. Mar. Labs. Carib. Curaçao 12: 21

Bak, R. P. M., Brouns, J. J. W M., Heys, F. M. L. (1977b). Regeneration and aspects of spatial competition in the scleractinian corals Agaricia agaricites and Montastrea annularis. In: Proceedings of Third International Coral Reef Symposium, Miami, Vol. 1, pp. 143-148 
Bak, R. P. M., Engel, M. S. (1979). Distribution, abundance and survival of juvenile hermatypic corals (Scleractinia) and the importance of life history strategies in the parent coral community. Mar Biol. 54: 341-352

Bak, R. P. M., Luckhurst, B. E. (1980). Constancy and change in coral reef habitats along depth gradients at Curaçao. Oecologia 47: 145-155

Bak, R. P. M, Steward-Van Es, Y. (1980). Regeneration of superficial damage in the scleractinian corals Agaricia agaricites, f. purpurea and Porites astreoides. Bull. mar. Sci. 30: 883-887

Benayahu, Y., Loya, Y. (1977). Space partitioning by stony corals, soft corals and benthic algae on the coral reefs of the northern Gulf of Eilat (Red Sea). Helgoländer wiss. Meeresunters. 30: 362-382

Berrill, N. J. (1948). The development, morphology and budding of the ascidian Diazona. J. mar. biol. Ass. U.K. 27 : 389-399

Burkholder, P. R. (1973). The ecology of marine antibiotics and coral reefs. In: Jones, O. A., Endean, R. (eds.) Biology and geology of coral reefs II. Biology 1. Academic Press, New Yusk, London, pp. 117-182

Carlisle, D. B. (1961). Locomotory powers of adult ascidians Proc. zool. Soc. Lond. 136: 141-146

Connell, J. H. (1976). Competitive interactions and the species diversity in corals. In: Mackie, G. O. (ed) Coelenterate ecology and behavior. Plenum Press, New York, pp. $51-58$

Connell, J. H. (1978). Diversity in tropical rain forests and coral reefs. Science, N.Y. 199: 1302-1310

Duyl, F. C., van, Bak, R. P. M., Sybesma, J. (1981). The ecology of the tropical compound ascidian Trididemnum solidum. I. Reproductive strategy and larval behaviour. Mar. Ecol. Prog. Ser. 6: 35-42

Glynn, P. W. (1973). Aspects of the ecology of coral reefs in the Western Atlantic Region. In: Jones, O. A., Endean, R. (eds.) Biology and geology of coral reefs II. Biology 1. Academic Press, New York, pp. 271-324

Goodbody, I. (1965). The biology of Ascidia nigra (Savigny). III. The annual pattern of colonization. Biol. Bull. mar. biol. Lab., Woods Hole 129: 128-133

Hoek, C. van den, Cortel-Breeman, A. M., Wanders, J. B. W. (1975). Algal zonation in the fringing reef of Curaçao, Netherlands Antilles, in relation to zonation of corals and gorgonians. Aquat. Bot. 1: 269-308

Hoek, C. van den, Breeman, A. M., Bak, R. P. M., Buurt, G. van (1978). The distribution of algae, corals and gorgonians in relation to depth, light attenuation, water movement and grazing pressure in the fringing coral reef of Curaçao, Netherlands Antilles. Aquat. Bot. 5: 1-46

Haven, N. D. (1971). Temporal patterns of sexual and asexual reproduction in the colonial ascidian Metadrocarpa taylori
Huntsman. Biol. Bull. mar biol. Lab., Woods Hole 140: $400-415$

Jackson, J. B. C., Buss, L. W (1975). Allelopathy and spatial competition among coral reef invertebrates. Proc natn. Acad. Sci. U.S.A. 72: 5160-5163

Kott, P. (1974). The evolution and distribution of Australian tropical Ascidiacea. In: Proceedings of Second International Coral Reef Symposium, Vol. 1 Great Bartier Reef Committee, Brisbane, pp. 406-423

Lafargue, F. (1972). Les Didemnidae (Protochadata) d'Helgoland. Helgoländer wiss. Meeresunters. 23: 100-116

Lang, J. C. (1970). Interspecific agression within the scleractinian reef corals. Ph. D. thesis, Yale University

Millar, R. H. (1952). The annual growth and reproduction cycle in four ascidians. J. mar biol. Ass. U.K. 31: 41-61

Millar, R. H. (1971). The biology of ascidians. Adv. mar. Sci. 9 $1-100$

Monniot, F. (1962). Recherches sur les graviers à Amphioxus de la region de Banyuls-sur-Mer. Vie Milieu 13: 231-322

Morgan, T O. (1977). Growth rate, age at sexual maturity, longevity, and seasonality in three West Indian colonial ascidians. M. Sc thesis, University of Puerto Rico, Mayagüez

Mukai, H., Watanabe, H. (1974). On the occurrence of colony specificity in some compound ascidians. Biol. Bull. mar. biol. Lab., Woods Hole 147: 411-421

Oka, H., Usui, M. (1944). On the growth and propagation of the colonies in Polycita mutabilis (Ascidiae compositae) Sci. Rep. Tôhoku Univ. (Ser 4) 33: 359-373

Oka, H., Watanabe, H. (1957). Colony-specificity in compound ascidians. Bull. Mar. Biol. Stat. Asamushi 10 $153-155$

Osman, R. W. (1977). The establishment and development of a marine epifaunal community. Ecol. Monogr 47: 37-63

Potts, D. C. (1977). Suppression of coral populations by filamentous algae within damselfish territories. J. exp. mar Biol. Ecol. 28, 207-216

Randall, J. E., Hartman, W D. (1968). Sponge-feeding fishes of the West Indies. Mar Biol. 1. 216-225

Sebens, K. P. (1976). The ecology of Caribbean sea anemones in Panama: utilization of space on a coral reef. In: Mackie, G. O. (ed.) Coelenterate ecology and behavior Plenum Press, New York, pp. $67-77$

Sybesma, J., Duyl, F. C. van, Bak, R. P. M. (1981). The ecology of the tropical compound ascidian Trididemnum solidum. III. Symbiosis with unicellular algae. Mar. Ecol. Prog. Ser

Vadas, R. L. (1979). Seaweeds: An overview; ecological and economic importance. Experimentia 35: 429-433

Yamaguchi, M. (1975). Growth and reproductive cycles of the marine fouling ascidians Ciona intestinalis, Styela plicata Botrylloides violaceus and Leptoclinum mitsukurii at Aburatsubo-Moroiso Inlet (Japan). Mar Biol. 29: 253-259 